\title{
Influence of groundwater on distribution of dwarf wedgemussels (Alasmidonta heterodon) in the upper reaches of the Delaware River, northeastern USA
}

\author{
Donald O. Rosenberry ${ }^{1}$, Martin A. Briggs ${ }^{2}$, Emily B. Voytek $^{3}$, and John W. Lane ${ }^{2}$ \\ ${ }^{1}$ US Geological Survey, MS 413, Bldg. 53, DFC, Denver, CO 80225, USA \\ ${ }^{2}$ US Geological Survey, 11 Sherman Place, Storrs, CT 06279, USA \\ ${ }^{3}$ Colorado School of Mines, 1500 Illinois Street, Golden, CO 80401, USA \\ Correspondence to: Donald O. Rosenberry (rosenber@usgs.gov)
}

Received: 21 April 2016 - Published in Hydrol. Earth Syst. Sci. Discuss.: 18 May 2016

Revised: 9 September 2016 - Accepted: 26 September 2016 - Published: 25 October 2016

\begin{abstract}
The remaining populations of the endangered dwarf wedgemussel (DWM) (Alasmidonta heterodon) in the upper Delaware River, northeastern USA, were hypothesized to be located in areas of greater-than-normal groundwater discharge to the river. We combined physical (seepage meters, monitoring wells and piezometers), thermal (fiberoptic distributed temperature sensing, infrared, vertical bedtemperature profiling), and geophysical (electromagneticinduction) methods at several spatial scales to characterize known DWM habitat and explore this hypothesis. Numerous springs were observed using visible and infrared imaging along the river banks at all three known DWM-populated areas, but not in adjacent areas where DWM were absent. Vertical and lateral groundwater gradients were toward the river along all three DWM-populated reaches, with median upward gradients 3 to 9 times larger than in adjacent reaches. Point-scale seepage-meter measurements indicated that upward seepage across the riverbed was faster and more consistently upward at DWM-populated areas. Discrete and areally distributed riverbed-temperature measurements indicated numerous cold areas of groundwater discharge during warm summer months; all were within areas populated by DWM. Electromagnetic-induction measurements, which may indicate riverbed geology, showed patterning but little correlation between bulk streambed electromagnetic conductivity and areal distribution of DWM. In spite of complexity introduced by hyporheic exchange, multiple lines of research provide strong evidence that DWM are located within or directly downstream of areas of substantial focused groundwater discharge to the river. Broad scale thermal-reconnaissance
\end{abstract}

methods (e.g., infrared) may be useful in locating and protecting other currently unknown mussel populations.

\section{Introduction}

The sediment-water interface is an important ecotone that harbors many organisms evolved to live in this dynamic environment. Areas where groundwater discharge to rivers is focused commonly are far less dynamic, particularly with regard to temperature and sediment saturation, and some organisms rely on this stability to survive (Hayashi and Rosenberry, 2002; Smith, 2005). Such may be the case for the endangered dwarf wedgemussel (Alasmidonta heterodon, family Unionidae). Formerly distributed throughout eastern North America from North Carolina to New Brunswick (Moser, 1993), this species is now endangered. It was thought to be extirpated in the upper Delaware River until populations were found along three reaches in 2000 (Cole et al., 2008). Water is diverted from three reservoirs in the upper tributaries to New York City. As a result, persistent low flows downstream from the dams during some summers may have contributed to the demise of formerly robust dwarf wedgemussel (DWM) populations. Given the precarious status of these three DWM populations, it is imperative to understand the processes that favor their viability.

Previous studies investigated whether the riverbed in these locations would become dry during low-flow events. Although low-flow conditions dewatered much of the riverbed, 
areas populated by DWM remained wetted as long as river discharge exceeded $15.8 \mathrm{~m}^{3} \mathrm{~s}^{-1}$ at the US Geological Survey (USGS) Callicoon gage (Cole et al., 2008). Another concern was excessively warm (or cold) water temperature. Other unionid mussel species are sensitive to warm water (Galbraith et al., 2012), and DWM are particularly sensitive (H. Galbraith, personal communication, 2014). Excessive shear stress also can reduce mussel populations (Hardison and Layzer, 2001; Layzer and Madison, 1995). Shear stress during high river stage in the three remaining DWMpopulated areas is smaller than the reach-averaged values (Maloney et al., 2012). Groundwater discharge may also be related to the location of mussel refugia (McRae et al., 2004), perhaps especially so in the upper Delaware River where groundwater discharge may locally diminish streambed dewatering (J. Cole, personal communication, 2013). Characterizing groundwater discharge dynamics to known patches of DWM is an important step toward a better understanding of their preferred habitat and successful management of the species.

Quantification of exchange between groundwater and surface water is particularly difficult in coarse-grained fluvial settings (e.g., González-Pinzón et al., 2015) due to spatial and temporal heterogeneity and multiple scales of flow that complicate distinction between hyporheic exchange and larger-scale groundwater discharge. Instruments are difficult to install where cobbles and boulders are present at and beneath the bed. Hydraulic gradients commonly are very small and difficult to resolve. Water chemistry is often a good method for distinguishing groundwater from surface water but, unfortunately, the chemistry of groundwater and surface water in the upper reaches of the Delaware River were found to be virtually identical.

Fortunately, use of several substantially different methods can minimize uncertainty and provide redundancy where some installations are difficult to impossible or when results based on a single method are inconclusive. The hydraulic head in water-table wells near the riverbank can be compared to river-surface elevations to evaluate the potential for lateral groundwater discharge on a reach scale. Electromagneticinduction methods can indicate changes in streambed geology over many kilometers, particular in areas where stream water and groundwater are of similar electrical conductivity (Ong et al., 2010). These methods can be used in combination with point-scale measurements to obtain a more comprehensive, process-based understanding of DWM habitat. Point-scale physical methods, such as in-river piezometers and seepage meters (Rosenberry et al., 2008), indicate the direction and magnitude of flow across the sediment-water interface at specific locations. Streambed vertical temperature profiles can also be used to determine seepage direction and rate, and can extend point-in-time measurements of water flux to month-long time series of sub-daily flux estimates using automated analytical (e.g., Irvine et al., 2015; Gordon et al., 2012) and numerical (e.g., Koch et al., 2015; Voytek et al., 2014) 1-D models. Other temperature-based methods can be used to separate groundwater discharge from superimposed hyporheic flow. Thermal infrared (TIR) and fiberoptic distributed temperature sensing (FO-DTS) methods are used to collect large field-of-view (100 s of m) or extensive longitudinal $(\mathrm{km})$ water-temperature measurements (Hare et al., 2015). TIR does not penetrate the water surface, whereas FO-DTS measures temperature along the sediment-water interface.

We used the above-listed methods to investigate the occurrence and distribution of groundwater discharge along three reaches of the upper Delaware River. Along each reach, which we refer to as sites, we compared results where DWM were present with results where they were absent. Specifically, we pursued three main goals:

1. determine the spatial distribution of the rate and direction of water exchange across the sediment-water interface related to the distribution of DWM populations;

2. evaluate temperature dynamics at the sediment-water interface during warm, summer low-flow periods to investigate larger-scale groundwater discharge distributions, and determine whether areas populated by DWM may serve as cold thermal refugia;

3. investigate the geology of the riverbed and relate groundwater-surface-water exchange to potential geologic controls.

During the course of the investigation, we discovered a relatively large spring within an area populated by DWM and studied in detail the thermal influence on adjacent and downstream water (Briggs et al., 2013). Here we expand the scope more broadly to address the three goals listed above with data collected at all three DWM-populated reaches of the Delaware River.

\section{Study area}

The three study sites containing DWM are within the $43 \mathrm{~km}$ reach of the upper Delaware River between Hancock and Callicoon, NY (Fig. 1). Prior to collection of data for this study, these sites were surveyed in 2012 by biologists familiar with DWM to determine the riverbed areas currently occupied by DWM. Each site encompassed areas where DWM were found as well as similar adjacent or nearby areas where DWM had never been found. Previous studies at these same three sites investigated minimum flows and temperature stability (Cole et al., 2008) and modeled shear stress related to occurrence of DWM (Maloney et al., 2012). Site 1 extends along the right (descending) side of a mid-channel island (Fig. 2a). Site 2 extends along a straight reach of the river where a single channel exists, and is centered above and below an ephemeral stream that enters the river on the right bank, approximately separating the known DWM area (M) 


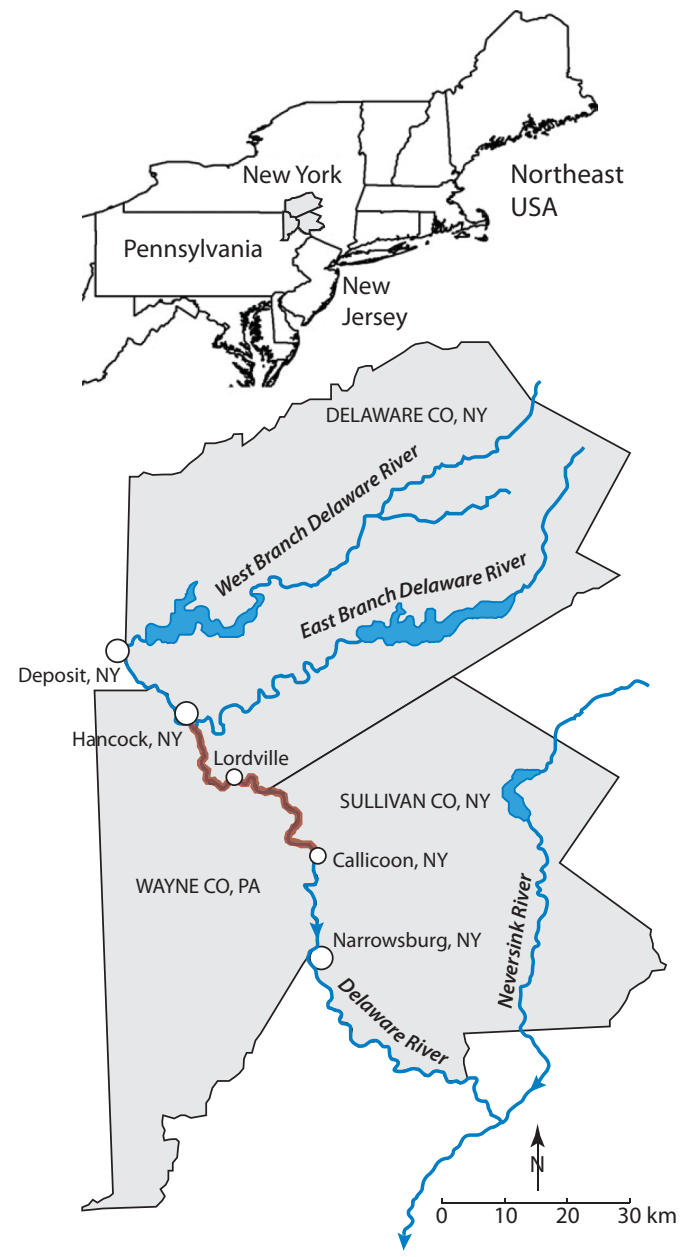

Figure 1. Delaware River reach (highlighted) on the border between New York and Pennsylvania between Hancock and Callicoon.

and non-mussel area (N) (Fig. 2b). The known M area at site 3 is situated along the south side of a mid-channel island, while the $\mathrm{N}$ area is on the north side (Fig. 2c). At site 3, DWM were found at various times over a 10-year period along the entire reach of the channel south of the mid-channel island. However, during the 2012 field season, DWM were found only along a $200 \mathrm{~m}$ reach at the downstream end of this channel (Fig. 2c). Because DWM were found upstream of the $\mathrm{M}$ reach prior to 2012, the upper portion of the channel was deemed inappropriate to serve as the $\mathrm{N}$ reach. Therefore, the $\mathrm{N}$ reach at site 3 was located across the mid-river island in the river channel to the left (north) of the island where current velocity was reduced. All locations are deliberately obscured to protect the endangered animals (Fig. 2).

Discharge $(Q)$ at Callicoon, the downstream end of the river reach containing the three sites, has been measured by USGS since 1975 (USGS station number 01427510; http://waterdata.usgs.gov/nwis). During 1975 through 2013, $Q$ ranged from $4078 \mathrm{~m}^{3} \mathrm{~s}^{-1}$ in June 2006 to $8.7 \mathrm{~m}^{3} \mathrm{~s}^{-1}$ in September 1997. The median $Q$ during the period of record

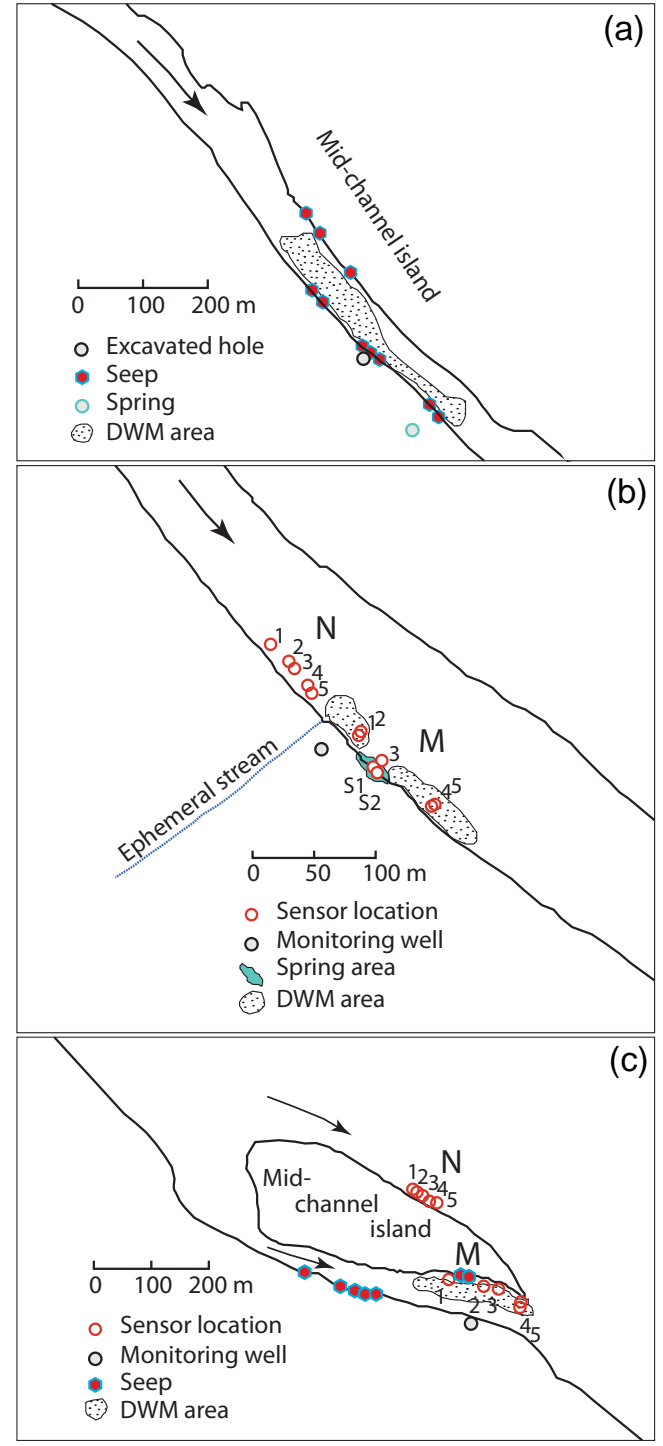

Figure 2. Sites 1 (a), 2 (b) and 3 (c). Arrows indicate direction of river flow. Sensor locations pertain to seepage-meter and in-river piezometer installations.

was $45.3 \mathrm{~m}^{3} \mathrm{~s}^{-1}$. River discharge during site visits in 2012 was close to a normally low value of about $30 \mathrm{~m}^{3} \mathrm{~s}^{-1}$, but discharge was much larger than normal during a site visit in 2013, ranging from 100 to $320 \mathrm{~m}^{3} \mathrm{~s}^{-1}$ (Fig. 3)

\section{Methods}

\subsection{Geomorphic parameters}

Grain-size distribution of the bed surface was determined using the Wolman (1954) pebble-count method over an approximately $100 \mathrm{~m}$ distance within each of the $\mathrm{M}$ and $\mathrm{N}$ reaches. River depth and flow velocity were measured at every $\mathrm{M}$ and $\mathrm{N}$ location at approximately the same time. River-surface 


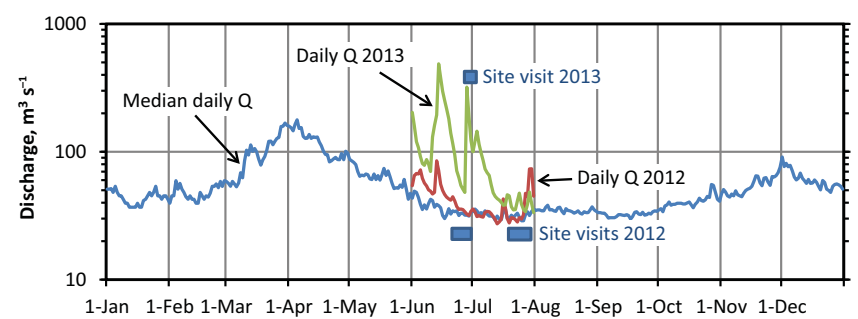

Figure 3. Median daily river discharge $(Q)$ based on the period of record 1975-2012 (USGS station number 01427510; http: //waterdata.usgs.gov/nwis). Daily-average $Q$ also is plotted during June-July 2012 and June-July 2013. Periods of site visits during 22 June-1 July 2012, 20-30 July 2012, and 28 June-2 July 2013, are shown as blue rectangles.

slope was surveyed along and beyond each $\mathrm{M}$ and $\mathrm{N}$ reach; combined with measurements of water depth, this provided a reach-averaged estimate of shear stress for each $\mathrm{M}$ and $\mathrm{N}$ reach. Shields stress, a dimensionless term that relates shear stress to the size of sediments on the bed (e.g., Buffington and Montgomery, 1997), was calculated and compared to critical Shields stress to determine the likelihood that the sediment bed was mobilized based on water depths measured during site visits.

Samples for water-quality analysis were collected from piezometers installed at each $\mathrm{M}$ and $\mathrm{N}$ location at sites 2 and 3, from water-table monitoring wells, from several seeps along the river bank, from the large spring/seep at site 2 (Fig. 2b), and from the river at each site. Groundwater and river chemistry were found to be universally similar; therefore, these results are not discussed in further detail.

\subsection{Evaluation of flow between groundwater and surface water}

\subsubsection{Visual and infrared observations}

Discharge of groundwater to the river was visually evident at all three sites. Flowing water either discharged along the bank just above the river surface (sites 1 and 2) or was visible as it discharged rapidly enough to suspend sediment just beneath the river surface (sites 1 and 3). A handheld TIR camera (FLIR T620, FLIR Systems, Inc., Nashua, NH) was used to locate and measure surface-temperature anomalies related to cold groundwater seepage near the streambank. TIR data were used to quickly discern between actively flowing seeps and other bank areas that were simply wet. TIR imagery represents only the temperature at the water or land surface; therefore, the cameras were most useful for identifying seeps at and landward of the shoreline and unmixed plumes of groundwater that reached the river surface (e.g., Hare et al., 2015). A bucket and stopwatch were used to quantify spring/seep discharge where conditions allowed.

\subsubsection{Lateral groundwater discharge potential}

A water-table monitoring well was installed adjacent to the right (southwest) bank of the river at each site to determine the hydraulic gradient between the water table and the river. Wells were installed using an auger to depths beneath land surface of 2.85 and $2.81 \mathrm{~m}$ at sites 2 and 3, respectively. At site 1 , a monitoring well could not be installed because boulders in the bank were too large and densely distributed to auger a hole. However, a $0.46 \mathrm{~m}$ deep hole was dug by hand to below the water table at a distance of $7.1 \mathrm{~m}$ from the river shoreline. This allowed a single measurement of horizontal hydraulic gradient at site 1 (Fig. 2a).

Discharge of groundwater to the river was calculated using the standard Darcy equation:

$Q=K i A$,

where $Q$ is the volumetric seepage rate $\left(\mathrm{m}^{3} \mathrm{~d}^{-1}\right), K$ is the horizontal hydraulic conductivity of the sediment between the well and the river shoreline $\left(\mathrm{m} \mathrm{d}^{-1}\right), i$ is the horizontal hydraulic gradient, which is the difference in head $(\mathrm{m})$ between the water level at the monitoring well and the river divided by the distance from the monitoring well to the shoreline (m), and $A$ is the cross-sectional area $\left(\mathrm{m}^{2}\right)$ of a vertical plane at the river shoreline through which water must pass as groundwater discharges to the river.

A single-well slug test (Bouwer and Rice, 1976; Bouwer, 1989) was conducted in each monitoring well to estimate $K$. Hydraulic head higher than the river stage indicates flow from groundwater to the river; $i$ is assigned a positive value for such a condition but $i$ also can be negative if the groundwater head is lower than river stage. Gradient and, therefore, $Q$ were determined every 20 min during July 2012 through June 2013 at sites 2 and 3 using data provided by Solinst submersible pressure transducers (Levelogger Edge, Junior and Barologger, Solinst Canada Ltd., Georgetown, Ontario, Canada) installed at fixed locations in each monitoring well, and in secure locations in the riverbed (Fig. 2b, c).

\subsubsection{Seepage meters}

Seepage meters directly measure water flow across an approximately $0.25 \mathrm{~m}^{2}$ portion of a sediment bed in units of volume per area per time. Seepage meters modified for use in flowing water (Rosenberry, 2008) were installed at five locations along each $\mathrm{M}$ and $\mathrm{N}$ reach indicated in Fig. 2. Locations along each $\mathrm{M}$ and $\mathrm{N}$ reach were numbered 1 through 5 with numbers increasing with distance downstream. Meters also were installed within a spring area (Briggs et al., 2013) at site 2 where sediments were soft, fine-grained, and markedly colder. Locations within the spring area were numbered S1 and S3 with numbers increasing with distance downstream. Multiple measurements ( $n$ ranged from 3 to 7 ) were made at each location as an estimate of measurement uncertainty with 

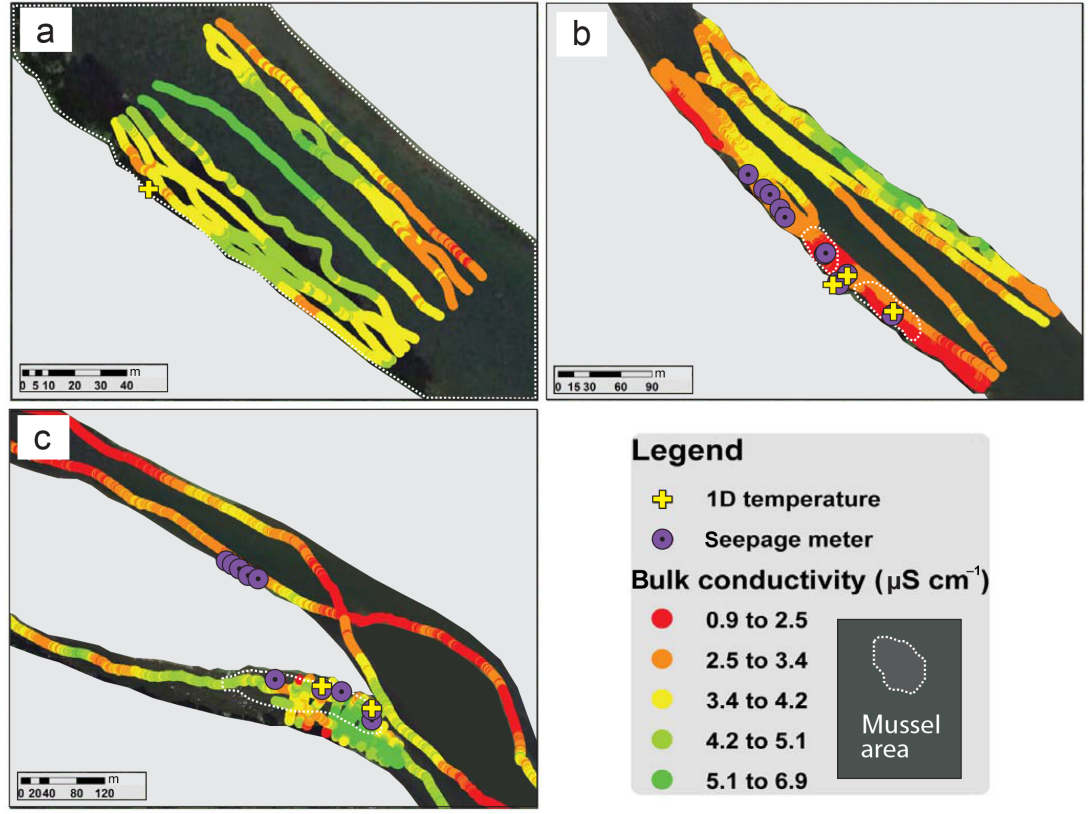

Figure 4. EMI quadrature data at $33030 \mathrm{~Hz}$ converted to bulk conductivity for (a) site 1, (b) site 2, and (c) site 3 . Warmer colors indicate less conductive streambed material potentially correlating to coarse-grained surficial deposits and bedrock.

the understanding that measurement uncertainty may be inflated if temporal variability is substantial.

\subsubsection{Streambed piezometers}

Similar to the riverbank monitoring wells, streambed piezometers can determine the potential for the direction of flow by measurement of hydraulic head within the streambed compared to the surface-water stage, but on a vertical axis. Streambed piezometers were installed directly adjacent to seepage meters at all $\mathrm{M}$ and $\mathrm{N}$ locations, except where installations were impossible due to buried boulders or where locations were so close together that one piezometer could represent both locations. Piezometers consisted of a stainless-steel pointed screen $(30 \mathrm{~mm}$ diameter and $85 \mathrm{~mm}$ screened interval) connected to $27 \mathrm{~mm}$ diameter galvanized pipe. Piezometers were driven to approximately 0.5 to $0.6 \mathrm{~m}$ depth beneath the riverbed. Completion depth was less than $0.5 \mathrm{~m}$ if, after several attempts, buried cobbles or boulders prevented deeper installation. In some locations where vertical head difference was very small, the piezometer was driven to a greater depth to create a measured head difference larger than the measurement error. Insertion depths ranged from 0.42 to $1.15 \mathrm{~m}$. In-river piezometers can indicate rates of exchange at the sediment-water interface if a value for $K$ is measured or assumed. However, as the seepage meters already provided a direct measure of flow across the sediment-water interface, vertical head gradients from the piezometers, $i_{\mathrm{v}}$, were combined with seepage rates from the seepage meters to determine a calculated value for vertical hydraulic conductivity, $K_{\mathrm{v}}$, at each location.

\subsubsection{Streambed vertical temperature profiler}

Surface temperature variations propagate downward into streambed sediments due to the sum of conduction and advection; if the conductive properties of the bed are measured or assumed, vertical advection can be determined using 1D analytical or numerical models (Constantz, 2008). Thermistor dataloggers (iButton Thermochron DS1921Z, Maxim Integrated, San Jose, CA) were installed at depths ranging from 0 to $0.4 \mathrm{~m}$ in 14 of the piezometers to provide temperature profiles with depth over time. These temperature records were collected for approximately 3 to 7 days. Strong, upward groundwater flow often reduces measurable diurnal signal penetration to less than $0.2 \mathrm{~m}$ (Briggs et al., 2014); therefore, at least 1 short complementary temperature profiler designed specifically to measure upward seepage was installed within the $\mathrm{M}$ zone at all three sites. These short profilers were constructed with four thermistor dataloggers (iButton Thermochron DS1922L) positioned at depths of only $0.01,0.04$, 0.07 , and $0.11 \mathrm{~m}$ beneath the riverbed. One such profiler was installed at site 1 in close proximity to an observed bankside seep, three profilers were installed at site 2 adjacent to seepage meters, and two were installed adjacent to seepage meters at the site $3 \mathrm{M}$ reach (Fig. 4; locations indicated as 1D temperature). Temperature records were collected for approximately 25 days.

Streambed-temperature time-series data were analyzed with the VFLUX program (Gordon et al., 2012) run in Matlab (Mathworks, Natick, MA). Diurnal signals were extracted from field data using VFLUX and applied to the 
amplitude-attenuation analytical model (as described by Hatch et al., 2006) because this model has been shown to be reliable in determining upward flow rates (Briggs et al., 2014). Error associated with sediment-property uncertainty was determined using Monte Carlo analysis and adjusting sediment thermal properties within expected ranges (Briggs et al., 2012b). This method of analysis provides the ability to resolve temporal patterns of vertical seepage at sub-daily time steps over the period of temperature-data collection.

\subsection{Temperature at the sediment-water interface}

A Sensornet Oryx (Sensornet House, Elstree, Hertfordshire, UK) fiber-optic distributed-temperature-sensing system (FODTS) was deployed on the riverbed at sites 2 and 3 to collect continuous temperature data in space and time along linear cables (e.g., Selker et al., 2006). The stainless-steelreinforced fiber-optic cables were distributed across $585 \mathrm{~m}$ of the streambed at site 2 and across $944 \mathrm{~m}$ of the streambed at site 3. The deployment at site 2 (21-24 July 2012) encompassed adjacent $\mathrm{M}$ and $\mathrm{N}$ reaches, while the site 3 installation (25-27 July 2012) only covered the M reach due to length limitations of the cable. FO-DTS data were analyzed to identify locations of anomalously cold temperature and small thermal variance that may correspond with focused groundwater seepage to the river (e.g., Briggs et al., 2012a), and thermal refuge for the DWM.

FO-DTS data were collected at 4 and 10 min intervals and calibration for thermal drift was performed using a continuously mixed ice bath monitored dynamically by a Sensornet thermistor-type thermometer. Approximately $30 \mathrm{~m}$ of cable were placed in the calibration ice bath. The standard deviation of the recorded FO-DTS temperatures in the ice bath, determined to be $0.07^{\circ} \mathrm{C}$, was used to estimate the precision of the FO-DTS datasets. The cable on the bed was georeferenced by correlating survey points taken with a Nivo $5 \mathrm{M}$ total station (Nikon-Trimble Co., Ltd, Tokyo, Japan) with meter marks printed on the cable jacket.

In addition to the spatial coverage provided by the linear FO-DTS cables, manual point (snapshot) measurements of streambed temperature were collected at $0.05 \mathrm{~m}$ sediment depth using a high-precision $\left(0.01^{\circ} \mathrm{C}\right)$ digital thermometer (Traceable Thermometer, Control Company, Friendswood, TX) at both $\mathrm{M}$ and $\mathrm{N}$ reaches of sites 2 and 3, similar to the method described by Lautz and Ribaudo (2012). Discrete bed temperatures were collected over approximately $2 \mathrm{~h}$ at site $2(n=107)$ on 22 July, and over $2.5 \mathrm{~h}$ at site 3 on 25 July $(n=149)$ at geo-referenced locations. Data were laterally interpolated to generate areal streambed-temperature maps using the ArcMap 10 (ESRI, Redlands, CA) "nearest neighbor" method.

\subsection{Geology of the riverbed}

Bedrock and unconsolidated materials have characteristic electrical-conductivity properties that can be sensed remotely with a variety of geophysical tools. Multi-frequency electromagnetic-induction (EMI) data were used to make inferences about underlying geologic structure of the streambed; EMI has been used previously to better constrain exchange between groundwater and surface water at landscape scales (e.g., Ong et al., 2010). These data were collected at all three sites using a portable digital, multi-frequency, electromagnetic conductivity sensor (GEM2; Geophex, Inc., Raleigh, NC) that measures the bulk apparent subsurface electrical conductivity (or magnetic susceptibility). Variance in electrical conductivity provides information about groundwater quality (e.g., salinity) or substrate properties, such as porosity. Larger conductivity values correspond to more conductive subsurface materials, such as shale bedrock or near-surface materials with a higher silt or clay fraction, whereas smaller conductivity values may indicate sandstone bedrock or coarser-grained surficial deposits. GEM-2 can be used to estimate streambed characteristics at depths up to approximately $12 \mathrm{~m}$ depending on streambed composition.

Multi-frequency EMI data were collected at all three sites. A fixed land location was established at each site and visited at the beginning and end of each survey to correct for instrument drift. The instrument was suspended about $1 \mathrm{~m}$ above the water surface using non-metallic PVC pipe secured inside an inflatable raft. A kayak and drogue were used to position the raft to provide areal coverage of the riverbed. All GEM-2 land locations and surveys were geo-referenced with an on-board GPS unit.

\section{Results}

\subsection{Geomorphic parameters}

Median water depths measured at site 2 during the June 2012 field visit were 0.58 and $0.59 \mathrm{~m}$ for M (DWM present) and $\mathrm{N}$ (DWM not present) locations, respectively. Median depths at site 3 for $\mathrm{M}$ and $\mathrm{N}$ locations were 0.41 and $0.44 \mathrm{~m}$, respectively (Table 1 ). Median river velocities were virtually identical between $\mathrm{M}\left(0.18 \mathrm{~m} \mathrm{~s}^{-1}\right)$ and $\mathrm{N}\left(0.17 \mathrm{~m} \mathrm{~s}^{-1}\right)$ measurement locations at site 2 . However, because the $\mathrm{N}$ locations at site 3 were in the wider and deeper channel north of the mid-channel island, median velocity at the $\mathrm{N}$ locations was nearly 4 times faster than at the M locations (Table 1 ). Only at locations M4 and M5 were current velocities at site 3 approximately the same as M-location velocities at site 2 .

Reach-averaged shear stress was nearly identical at the $\mathrm{M}$ and $\mathrm{N}$ locations at site 2, primarily because the slope of the river surface (0.00037) was the same at both reaches. The $\mathrm{M}$ reach at site 3 also had virtually the same slope (Table 1 ). 
Table 1. Median values for parameters measured at each installation location at sites 2 and 3.

\begin{tabular}{|c|c|c|c|c|c|c|c|c|c|c|c|c|c|c|c|}
\hline Site & Location & $\begin{array}{l}u \\
\left(\mathrm{~m} \mathrm{~s}^{-1}\right)\end{array}$ & $\begin{array}{l}h \\
(\mathrm{~m})\end{array}$ & $\begin{array}{r}q \\
\left(\mathrm{~cm} \mathrm{~d}^{-1}\right)\end{array}$ & $\begin{array}{l}l \\
(\mathrm{~m})\end{array}$ & $i$ & $\begin{array}{r}K_{\mathrm{V}} \\
\left(\mathrm{m} \mathrm{d}^{-1}\right)\end{array}$ & $\begin{array}{l}\text { Med } \\
u\end{array}$ & $\begin{array}{l}\text { Med } \\
K_{\mathrm{V}}\end{array}$ & $\begin{array}{l}\text { Med } \\
h\end{array}$ & $\begin{array}{r}\text { Med } \\
q\end{array}$ & $\begin{array}{l}\text { Med } \\
i\end{array}$ & $\begin{array}{l}\tau \\
\left(\mathrm{N} \mathrm{m}^{-2}\right)\end{array}$ & $\begin{array}{l}D_{50} \\
(\mathrm{~mm})\end{array}$ & $\tau^{*}$ \\
\hline \multirow{5}{*}{ Site 2} & M1 & 0.18 & 0.52 & 0.43 & 0.28 & 0.0088 & 0.5 & \multirow{5}{*}{0.18} & \multirow{5}{*}{0.5} & \multirow{5}{*}{0.58} & \multirow{5}{*}{0.43} & \multirow{5}{*}{0.009} & \multirow{5}{*}{1.85} & \multirow{5}{*}{33} & \multirow{5}{*}{0.003} \\
\hline & M2 & & 0.61 & -2.32 & & & & & & & & & & & \\
\hline & M3 & 0.17 & 0.57 & 0.52 & 0.44 & 0.0079 & 0.7 & & & & & & & & \\
\hline & M4 & 0.23 & 0.58 & 0.13 & 0.18 & 0.0114 & 0.1 & & & & & & & & \\
\hline & M5 & & 0.61 & 0.43 & & & & & & & & & & & \\
\hline \multirow{5}{*}{ Site 2} & N1 & 0.16 & 0.59 & 0.42 & 0.65 & 0.0031 & 1.3 & \multirow{5}{*}{0.17} & \multirow{5}{*}{1.3} & \multirow{5}{*}{0.59} & \multirow{5}{*}{0.18} & \multirow{5}{*}{0.003} & \multirow{5}{*}{1.70} & \multirow{5}{*}{4.4} & \multirow{5}{*}{0.024} \\
\hline & $\mathrm{N} 2$ & & 0.61 & 0.14 & 1.15 & 0.0035 & 0.4 & & & & & & & & \\
\hline & N3 & 0.17 & 0.63 & 18.06 & 0.68 & 0.0044 & 40.9 & & & & & & & & \\
\hline & N4 & & 0.57 & -0.38 & 1.09 & -0.0004 & 9.6 & & & & & & & & \\
\hline & N5 & 0.17 & 0.50 & 0.18 & 0.36 & 0.0084 & 0.2 & & & & & & & & \\
\hline \multirow[t]{2}{*}{ Site 2} & $\mathrm{~S} 1$ & 0 & 0.27 & 0.56 & 0.60 & 0.0168 & \multirow[t]{2}{*}{0.3} & & & & & & & & \\
\hline & $\mathrm{S} 3$ & 0.03 & 0.52 & 2.20 & & & & & & & & & & & \\
\hline \multirow{5}{*}{ Site 3} & M1 & 0.04 & 0.36 & 3.55 & 0.55 & 0.0009 & 39.4 & \multirow{5}{*}{0.08} & \multirow{5}{*}{12.5} & \multirow{5}{*}{0.41} & \multirow{5}{*}{3.55} & \multirow{5}{*}{0.009} & \multirow{5}{*}{1.36} & \multirow{5}{*}{43} & \multirow{5}{*}{0.002} \\
\hline & M2 & 0.06 & 0.50 & 6.96 & 0.59 & 0.0118 & 5.9 & & & & & & & & \\
\hline & M3 & 0.08 & 0.41 & 3.5 & 0.42 & 0.0072 & 4.9 & & & & & & & & \\
\hline & M4 & 0.11 & 0.38 & -0.12 & & & & & & & & & & & \\
\hline & M5 & 0.19 & 0.50 & 26.92 & 1.39 & 0.0140 & 19.2 & & & & & & & & \\
\hline \multirow{5}{*}{ Site 3} & N1 & 0.26 & 0.38 & -0.01 & & & & & & & & & & & \\
\hline & $\mathrm{N} 2$ & 0.34 & 0.46 & 84.22 & 0.56 & 0.0027 & 313.0 & & & & & & & & \\
\hline & N3 & 0.31 & 0.44 & 17.91 & 0.56 & 0.0009 & 202.2 & 0.31 & 202.2 & 0.44 & -0.01 & 0.001 & 4.71 & 55 & 0.005 \\
\hline & N4 & 0.31 & 0.43 & -4.75 & 0.55 & -0.0119 & 4.0 & & & & & & & & \\
\hline & N5 & 0.30 & 0.58 & -0.01 & & & & & & & & & & & \\
\hline
\end{tabular}

$K_{\mathrm{V}}$, vertical hydraulic conductivity determined at each in-river piezometer. $\tau$, reach-average shear stress. $D_{50}$, median grain size of bed surface. $\tau^{*}$, reach-average Shields stress.

The slope at the $\mathrm{N}$ reach at site 3 was nearly twice as large at 0.00065 . Therefore, shear stress at site 3, reach $\mathrm{N}$, was more than double that of any of the other reaches. Shields stress (Table 1) at all reaches was well below commonly assumed critical values of 0.03 to 0.06 required for bed mobility (e.g., Shvidchenko et al., 2001).

River slope and water depths were not measured at site 1. Maloney et al. (2012) indicated that water depth, current velocity, and shear stress at site 1 are similar to site 2 during river discharge (less than about $100 \mathrm{~m}^{3} \mathrm{~s}^{-1}$ ). Cole et al. (2008) also indicated similar water depths between sites 1 and 2 in portions of the riverbed where DWM are known to be present.

\subsection{Groundwater-surface-water exchange}

\subsubsection{Visual and infrared observations}

Walking along the site 1 riverbank within, above, and below the reach where DWM have been identified revealed 10 bank-side seeps on both sides of the channel southwest of the mid-channel island (Fig. 2a). Small wetland areas of approximately 10 to $30 \mathrm{~m}^{2}$ areal extent also existed uphill of the seeps southwest of the channel, particularly in the area where the monitoring-well excavation was made (Fig. 2a). These wetland areas were situated 1 to $1.5 \mathrm{~m}$ above the river surface and between 2 and $8 \mathrm{~m}$ from the riverbank and were characterized by saturated soft sediments. Seeps along the left bank (island side) of the southern channel were more dis- tinctly located. Discharge at the seep adjacent to the northernmost extent of the DWM area in Fig. 2a was sufficient to cause groundwater sapping, resulting in landward erosion of sediment along a 0.1 to $0.2 \mathrm{~m}$ vertical face at the shoreline. Bankside seeps were neither identified within $200 \mathrm{~m}$ upstream of the northernmost seep or downstream of the southernmost seeps in Fig. 2a, nor were any seeps identified along the north side of the island. A spring situated uphill from the river along a road cut discharged $6.4 \mathrm{~L} \mathrm{~min}^{-1}$.

The spring area at site 2 (Figs. $2 \mathrm{~b}$ and 5) included two areas approximately $0.1 \mathrm{~m}$ in diameter and separated by about $0.5 \mathrm{~m}$ that discharged copious amounts of water and is described in detail in Briggs et al. (2013). The smaller spring discharged $12.9 \mathrm{~L} \mathrm{~min}^{-1}$ and the larger spring discharged $76.5 \mathrm{~L} \mathrm{~min}^{-1}$ at a nearly constant rate. Combined, they discharged nearly $129 \mathrm{~m}^{3} \mathrm{~d}^{-1}$. TIR imagery at site 2 indicated water issuing from these two spring discharge points had a steady temperature of $10.8^{\circ} \mathrm{C}$. This cold, dense plume of unmixed groundwater plunged into the river within $2 \mathrm{~m}$ of the shoreline (Fig. 5). A small volume of discharge also originated at the mouth of the ephemeral stream that was about $40 \mathrm{~m}$ upriver of the large seep area (Fig. 2b). No other bankside seeps were identified along or adjacent to this study reach nor were any observed along the northern riverbank opposite the study area.

At site 3, the riverbank immediately southwest of the riverbed area where DWM have been located did not contain any obvious seeps, but the 10 to $15 \mathrm{~m}$ wide bench imme- 

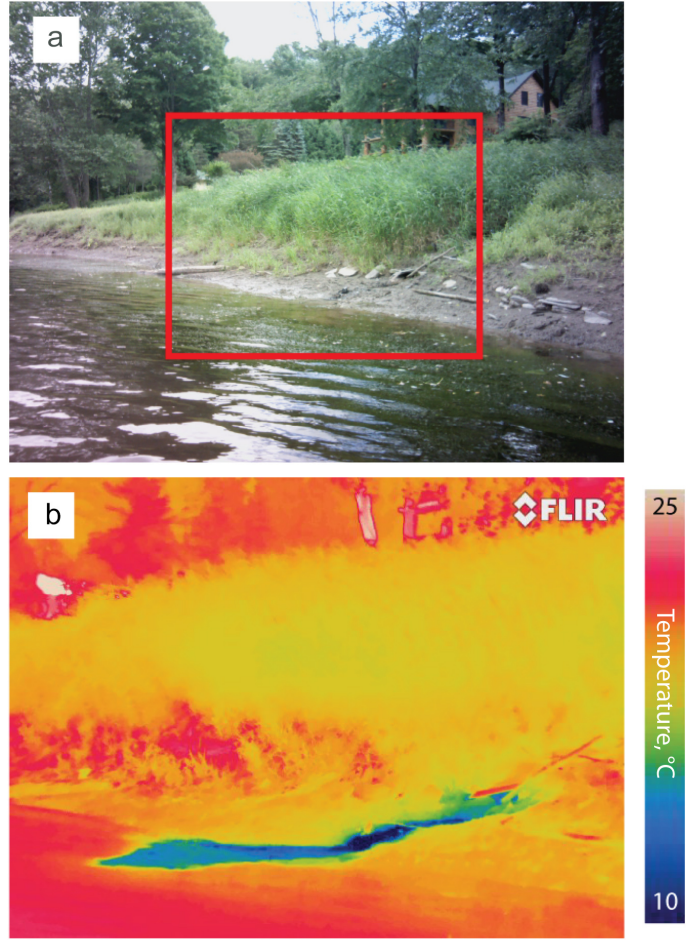

Figure 5. (a) Photograph of riverbank at site 2 with red rectangle indicating area of infrared image (b). Color infrared image with blue area showing colder groundwater entering the river. Color scale indicates temperature, in ${ }^{\circ} \mathrm{C}$.

diately adjacent to the shoreline was soft and wet in areas. Two seeps were identified at the shoreline next to the midchannel island, approximately equidistant from the two westernmost M locations (Fig. 2). These seeps discharged water both above and below the shoreline and suspended sand where the discharge point was submerged. Five other colder seeps were located upriver along the right bank (south side) of the channel. The discharge point at all of the right-bank seeps was 0.1 to $0.2 \mathrm{~m}$ above the river surface. Although difficult to measure, several of the seeps were discharging at approximately 0.5 to $2 \mathrm{~L} \mathrm{~min}^{-1}$. Seeps along the mid-channel island at site 3 were universally warmer $\left(22.6-25.7^{\circ} \mathrm{C}\right)$ than those observed at other sites. Seeps on the south side of the channel at site 3 were not measured but they were noticeably colder than the island seeps and were similar in temperature to the site 2 seeps. Temperature in the monitoring wells at sites 2 and 3 averaged 11.9 and $11.4^{\circ} \mathrm{C}$, respectively, during the period when spring and seep temperatures were measured.

\subsubsection{Lateral groundwater discharge potential}

The single measurement of hydraulic gradient $(i)$ at site 1 during the afternoon of 26 July 2012 resulted in a value of 0.17 , indicating a large potential for groundwater to discharge to the river. The stabilized water level in the exca- vation was $1.22 \mathrm{~m}$ above river stage. With no value for $K$ for this location, no attempt was made to determine the rate of groundwater discharge to the river along this reach. This measurement was made during a prolonged period of relatively steady river discharge that began on 24 June and likely represents largely steady-state conditions.

The median value for $i$ at site 2, determined over nearly a year, was 0.08 (Fig. 6a), also quite large for sandy sediments. Values were typically close to 0.07 during summer months and increased to about 0.10 starting in November and continuing until mid-March. The smallest gradients, other than during gradient reversals, occurred during mid-May to mid-June when river stage rose to a greater extent than groundwater. $K$ based on analysis of slug-test data from the site 2 monitoring well was $6.3 \times 10^{-2} \mathrm{~m} \mathrm{~d}^{-1}$, indicative of silty sand. The estimate of the thickness of quaternary alluvium and underlying transmissive fractured sandstone was based on Braun (2011) and Martin et al. (1985). Assuming the transmissive sediment between the riverbed and the underlying bedrock is 10 to $20 \mathrm{~m}$ thick, and assuming that all of the horizontal flow of groundwater to the river occurs through this 10 to $20 \mathrm{~m}$ thick vertical cross section of sand and fractured shallow sandstone before discharging to the river, groundwater discharge to the river at site 2 would be 0.04 to $0.07 \mathrm{~L} \mathrm{~min}^{-1}$ per meter of river reach. For the entire site 2 reach, groundwater discharge would be about 10 to $20 \mathrm{~m}^{3} \mathrm{~d}^{-1}$. This is likely an underestimate as slug tests generally yield smaller values of $K$ than more scale-appropriate methods (e.g., Schulze-Makuch et al., 1999; Rovey II and Cherkauer, 1995).

The median value for hydraulic gradient based on the monitoring well at site 3 was 0.05 (Fig. 6c). Other than during high-discharge events, the median value was remarkably stable during the period of record. The gradual decrease in hydraulic gradient from late July until early September 2012, is likely a return to hydrostatic conditions following well installation and indicative of the low $K$ of the sediments at the well. More than a month was required for the water level inside the well to stabilize. Slug tests indicate that $K$ is $8.5 \times 10^{-5} \mathrm{~m} \mathrm{~d}^{-1}, 3$ orders of magnitude smaller than at site 2. Making the same assumption that groundwater discharge to the river occurs through a vertical plane at the shoreline that is 10 to $20 \mathrm{~m}$ thick, groundwater discharge at site 3 would be on the order of 3 to $6 \times 10^{-5} \mathrm{~L} \mathrm{~min}^{-1}$ per $\mathrm{m}$ of river reach, or 0.03 to $0.06 \mathrm{~m}^{3}$ day $^{-1}$ for the entire site 3 reach. Given the numerous springs in this area, this slow, diffuse groundwater discharge clearly is augmented by focused groundwater discharge through preferential flow paths.

Relative river stage and water level in the adjacent groundwater monitoring well are plotted in Fig. 6 for sites 2 and 3 . Values are adjusted so river stage approximately equals the water depth at each in-river pressure transducer. As the river stage rose, the shoreline moved laterally and the distance between the shoreline and the monitoring well decreased. Calculations of $i$ incorporated a linear interpolation of reduced horizontal distance with increasing river stage, with a min- 

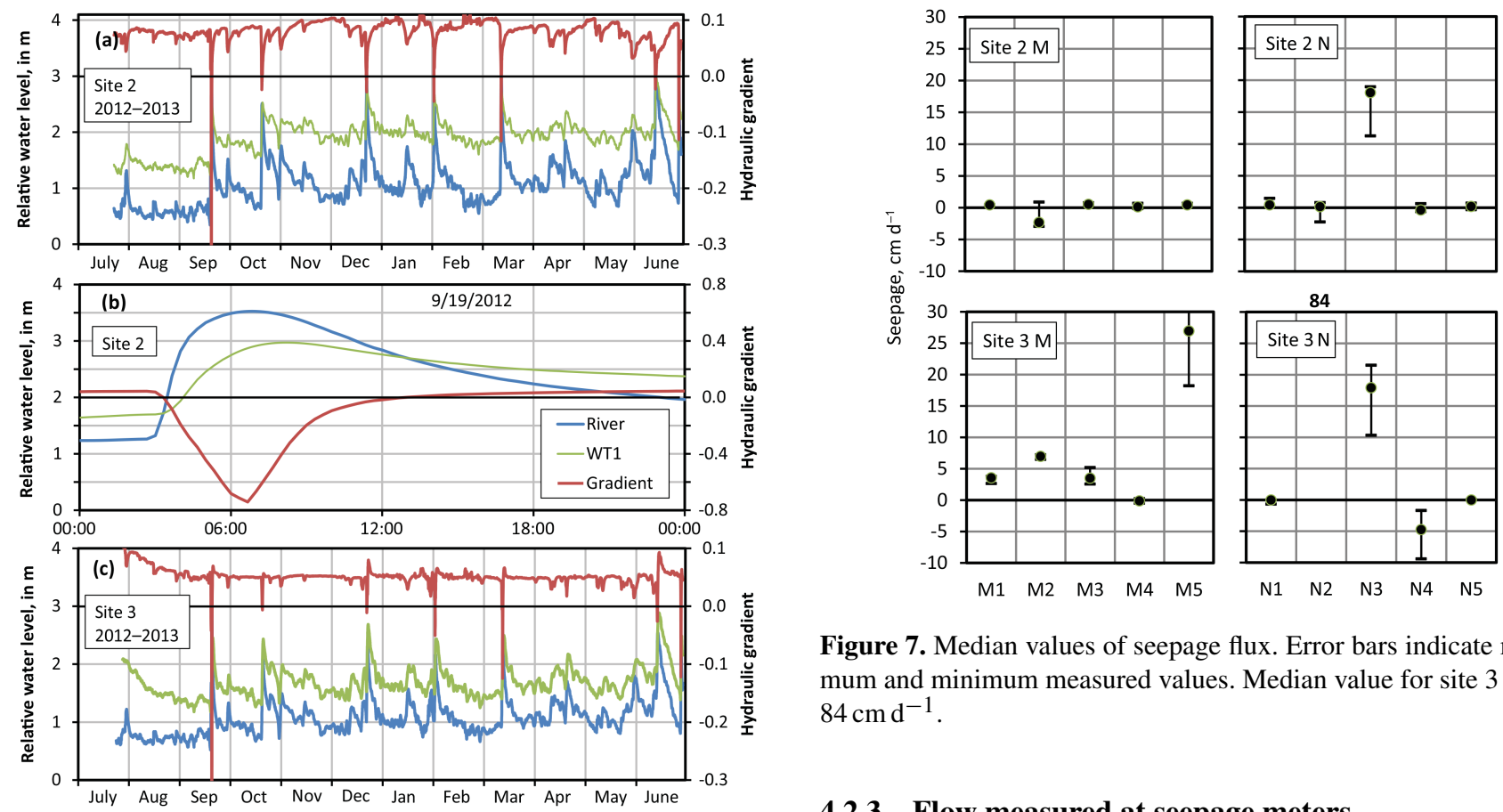

Figure 7. Median values of seepage flux. Error bars indicate maximum and minimum measured values. Median value for site 3 N2 is $84 \mathrm{~cm} \mathrm{~d}^{-1}$.

\subsubsection{Flow measured at seepage meters}

Figure 6. River stage, water-table elevation, and hydraulic gradient at sites 2 and 3. Legend in panel (b) also applies to panels (a) and (c) except site 3 data are from the WT2 monitoring well. (a) Site 2, July 2012 through June 2013; (b) 20 min data from site 2 showing gradient reversal on 19 September 2012; (c) site 3, July 2012 through June 2013.

imum horizontal distance of $0.9 \mathrm{~m}$ occurring at a maximum relative river stage of $3.53 \mathrm{~m}$ at site 2 , and a minimum horizontal distance of $0.7 \mathrm{~m}$ occurring at a maximum relative river stage of $2.93 \mathrm{~m}$ at site 3 . At both sites, maximum river stage occurred on 19 September 2012 (Fig. 6), indicating the high-stage river shoreline did not quite reach the locations of the monitoring wells.

During the 1-year period from July 2012 through June 2013, the hydraulic gradient at both sites 2 and 3 reversed and became negative 7 times in response to a rising river stage that preceded and exceeded a corresponding rise in the water table at the monitoring wells. This effect is displayed in Fig. $6 \mathrm{~b}$ for the largest rise in river stage at site 2 on 19 September. The rapid increase in river stage from 03:00 to 06:00 LT was substantially larger than the responding increase in head at well WT1, resulting in a reversal of hydraulic gradient that exceeded -0.7 for a short time. The gradient reversal was short lived, however, lasting only about $10 \mathrm{~h}$. An upward hydraulic gradient was re-established at about 13:00 LT. Furthermore, even though river stage at 22:00 LT was still $0.75 \mathrm{~m}$ higher than it was prior to the highstage event, hydraulic gradient had already returned to the pre-event value of 0.04 .

Seepage was generally small at all but a few $\mathrm{M}$ and $\mathrm{N}$ measurement locations. Median values of seepage were upward at 8 of $10 \mathrm{M}$ locations and at 6 of $10 \mathrm{~N}$ locations. Both $\mathrm{M}$ reaches had positive (upward) median values ( 0.43 and $3.55 \mathrm{~cm} \mathrm{~d}^{-1}$ ) and both were larger than median values for the $\mathrm{N}$ reaches $\left(0.18\right.$ and $\left.-0.01 \mathrm{~cm} \mathrm{~d}^{-1}\right)$ (Table 1$)$. The only reach where seepage was substantially upward was the $\mathrm{M}$ reach at site 3, where upward seepage at 4 of 5 locations was greater than $3 \mathrm{~cm} \mathrm{~d}^{-1}$. Seepage was more variable at $\mathrm{N}$ reaches than at $\mathrm{M}$ reaches, particularly so if the site $3 \mathrm{M} 5$ value is excluded (Fig. 7). Seepage at that location was much more variable due to increased turbulence where two channels merge into a single channel. The large variability at the $\mathrm{N}$ reach of site 3 (Table 1) was undoubtedly due to the larger current velocity, shear stress, and greater hyporheic exchange there.

Seepage at locations S1 and S3 at site 2 was only slightly to moderately faster relative to seepage measured at nearby M locations (Table 1). Although larger rates of seepage were expected within this cold-water spring area, detailed temperature measurements indicated that most of the seepage, and the source of the cold water at the streambed, originated landward of the shoreline (Briggs et al., 2013).

\subsubsection{Streambed piezometers}

Vertical hydraulic gradients $\left(i_{\mathrm{v}}\right)$ measured at in-river piezometers were generally small and indicated the potential for upward flow at all $\mathrm{M}$ locations and at 6 of $8 \mathrm{~N}$ locations. Where $i_{\mathrm{v}}$ was negative (site $2 \mathrm{~N} 4$, site $3 \mathrm{~N} 4$ ), indicating the potential for downward flow, $q$ determined with seepage meters was also negative, indicating downward flow (Table 1). The median of M-reach $i_{\mathrm{v}}$ measurements was 0.009 at both 
$\mathrm{M}$ reaches. Median values at $\mathrm{N}$ reaches were 0.003 and 0.001 for sites 2 and 3, respectively. The piezometer installed at $\mathrm{S} 1$ in the spring area at site 2 (Figs. $2 \mathrm{~b}$ and $5 \mathrm{a}$ ) indicated a relatively large $i_{\mathrm{v}}$ of 0.017 .

Calculated $K_{\mathrm{v}}$ at about half of the measured locations was smaller than expected for a gravel- to cobble-bedded river, indicating that finer-grained sediments were present between the bed surface and the well screen at some locations. Values for $K_{\mathrm{v}}$ ranged from 0.1 to $39 \mathrm{~m} \mathrm{~d}^{-1}$ at M-reach locations and from 0.2 to $313 \mathrm{~m} \mathrm{~d}^{-1}$ at $\mathrm{N}$-reach locations. The two largest $K_{\mathrm{V}}$ values were at $\mathrm{N} 2$ and $\mathrm{N} 3$ at site 3 , where the current is faster and cobbles are larger. These values, both larger than $100 \mathrm{~m} \mathrm{~d}^{-1}$, are indicative of coarse sand or gravel. Median values of $K_{\mathrm{v}}$ determined at M reaches were 0.5 and $12.5 \mathrm{~m} \mathrm{~d}^{-1}$ at sites 2 and 3, respectively. Median values of $K_{\mathrm{v}}$ at corresponding $\mathrm{N}$ reaches were 1.3 and $202 \mathrm{~m} \mathrm{~d}^{-1}$. The value for $K_{\mathrm{v}}$ at location S1 in the spring area was only $0.3 \mathrm{~m} \mathrm{~d}^{-1}$ (Table 1), indicative of silty sand, such as was observed on the bed in this area.

\subsubsection{Streambed vertical temperature profilers}

Vertical seepage rates determined with VFLUX from the thermal records collected in piezometers varied substantially depending on which pair of thermometers was used to calculate $q$ (Table 2). At site 2, thermal results indicated that rapid downward seepage near the surface of the riverbed decreased with depth at locations M3 and N3, whereas seepage-meter results indicated small (M3) to moderate (N3) upward seepage. Results at site $3 \mathrm{~N} 3$ were similar to those at site $2 \mathrm{~N} 3$ but with smaller values. Only at site 3 M5 did the thermal profiler records collected in piezometers and seepage-meter results indicate seepage in generally the same direction. Results from thermal models and seepage-meter values were similar at M2 and also at M5 if the 30-50 paired thermometers were used (Table 2).

Seepage determined with temperature data from the shallow profilers designed to capture upward flow averaged $16 \mathrm{~cm} \mathrm{~d}^{-1}$ at site 1 (installed near a visible bankside seep) and steadily decreased over the recording period (Fig. 8). Shallow profiler seepage at site 2 near the main spring ( 2 to $3 \mathrm{~m}$ from the $\mathrm{S} 1$ and $\mathrm{S} 3$ seepage meters) averaged $27 \mathrm{~cm} \mathrm{~d}^{-1}$ and varied from 12 to $39 \mathrm{~cm} \mathrm{~d}^{-1}$ (Fig. 8, uppermost red line). The remaining profiler data from two of the three locations at site 2 , and both locations at site 3 , showed fairly consistent fluid flux that can be described as "circumneutral" as they ranged within the expected error bounds of $\pm 10 \mathrm{~cm} \mathrm{~d}^{-1}$ associated with this method in this coarse-grained setting (Fig. 8). All four of these circumneutral plots show two downward spikes in seepage, the latter coincident with an upward spike in river stage and discharge measured at the USGS gage in Callicoon.

Slow seepage-flux estimates in the range of $\pm 10 \mathrm{~cm} \mathrm{~d}^{-1}$ from profilers at sites 2 and 3 generally correspond with nearby seepage-meter rates ranging from 0.5 to $7.0 \mathrm{~cm} \mathrm{~d}^{-1}$.

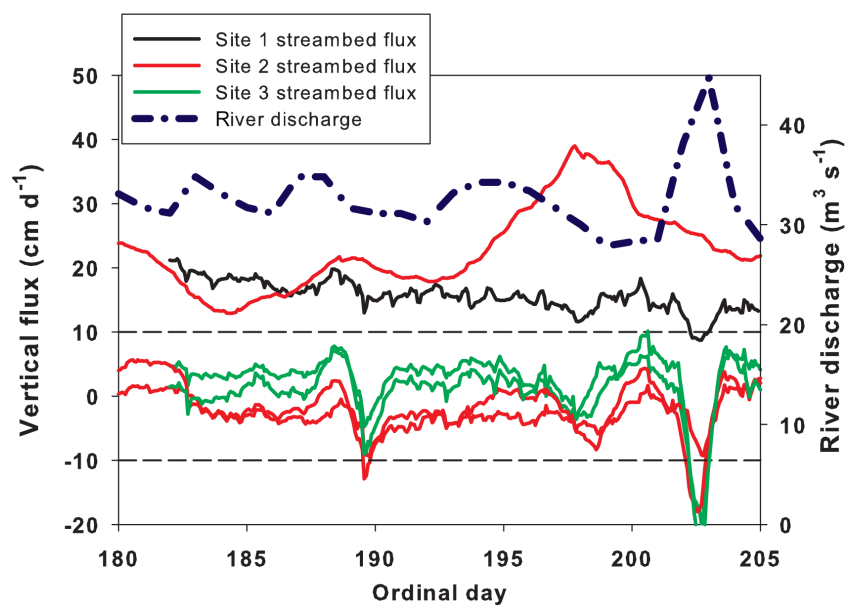

Figure 8. Seepage rates determined with VFLUX and Delaware River discharge determined over 25-day period from 28 June23 July.

Table 2. Comparison of time-averaged VFLUX seepage values and median seepage-meter values at select locations.

\begin{tabular}{lcrrr}
\hline Site & Location & $\begin{array}{r}\text { Interval } \\
(\mathrm{cm})\end{array}$ & $\begin{array}{r}\text { VFLUX } \\
\left(\mathrm{cm} \mathrm{d}^{-1}\right)\end{array}$ & $\begin{array}{r}\text { Seepage meter } \\
\left(\mathrm{cm} \mathrm{d}^{-1}\right)\end{array}$ \\
\hline 2 & M3 & $0-10$ & -69.2 & 0.5 \\
2 & M3 & $10-20$ & -12.1 & 0.5 \\
2 & M3 & $20-40$ & -9.9 & 0.5 \\
2 & N3 & $0-10$ & -32.2 & 18.1 \\
2 & N3 & $10-20$ & -18.6 & 18.1 \\
2 & N3 & $20-30$ & -10.2 & 18.1 \\
2 & N3 & $30-50$ & -5.0 & 18.1 \\
3 & M2 & $0-10$ & 4.4 & 7 \\
3 & M5 & $10-20$ & -11.1 & 26.9 \\
3 & M5 & $20-30$ & 0.5 & 26.9 \\
3 & M5 & $30-50$ & 32.5 & 26.9 \\
3 & N3 & $0-20$ & -19.7 & 17.9 \\
3 & N3 & $20-30$ & -6.9 & 17.9 \\
3 & N3 & $30-50$ & -4.4 & 17.9 \\
\hline
\end{tabular}

The $27 \mathrm{~cm} \mathrm{~d}^{-1}$ value from the profiler installed near the spring area at site 2 was substantially larger than values of 0.56 and $2.20 \mathrm{~cm} \mathrm{~d}^{-1}$ measured at the S1 and S3 seepage meters. The profiler value was similar to seepage determined at four high-resolution temperature sensors installed in the spring area for a related study that averaged from 12 to $35 \mathrm{~cm} \mathrm{~d}^{-1}$ (Briggs et al., 2013).

\subsection{Temperature at the sediment-water interface}

Average FO-DTS temperatures collected over 4 days at site 2 ranged from 14.0 to $22.5^{\circ} \mathrm{C}$ (Fig. 9). A slightly colder zone was detected along a $115 \mathrm{~m}$ length of cable located closer to shore along much of the $\mathrm{M}$ reach and into the southern portion of the $\mathrm{N}$ reach. Discharge of cold groundwater should 

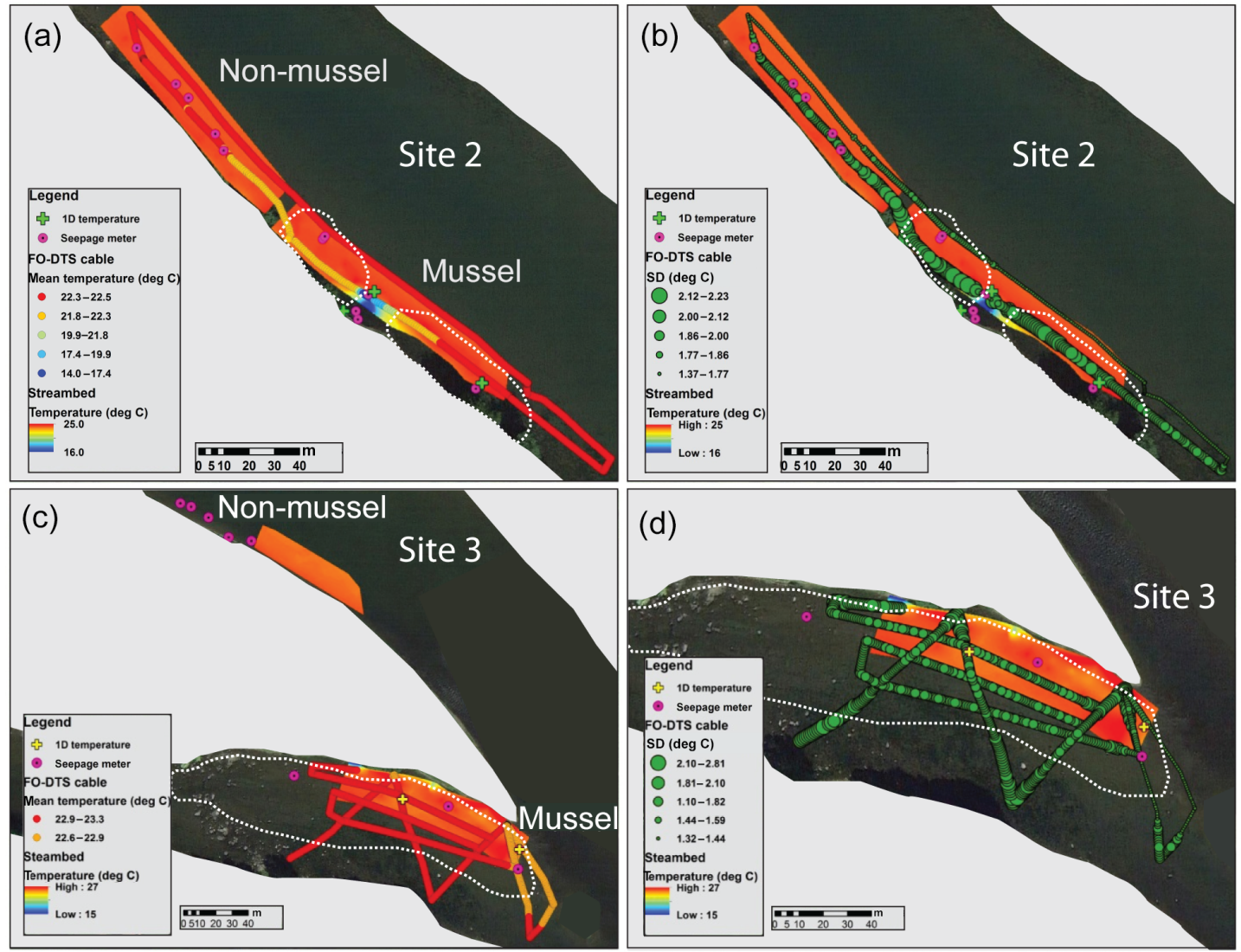

Figure 9. Riverbed temperatures indicated by snapshot thermal surveys (shaded riverbed areas) and FO-DTS at site 2 (panels a, b) and site 3 (panels (c), (d)). Colored circles in panels (a) and (c) indicate temperature and sizes of circles in panels (b) and (d) indicate temperature standard deviation during 4- and 2-day cable deployments at site 2 and 3, respectively.

result in decreased variance but temperature variance along the site 2 FO-DTS cable is actually largest for the colder areas, except at the bankside seep depicted in Fig. 5 (Fig. 9b). The larger variance is likely due to the nearshore cable along the cold reach being situated in shallow, clear water that often results in solar heating of the interface and cables (Neilson et al., 2010). This is supported by data from the cable located further from shore that shows reduced thermal variance. Average FO-DTS data collected over 2 days at the site $3 \mathrm{M}$ reach have a much tighter range of 22.6 to $23.3^{\circ} \mathrm{C}$. Temperature variance (Fig. 9d) is relatively large throughout the shallow-water area south of the island point bar, but is greatly reduced where the cable passes through stronger current from the channel that originates on the north side of the mid-river island.

Temperatures measured with the snapshot streambed thermal surveys at sites 2 and 3 are generally similar to patterns shown in the FO-DTS data. However, the snapshot data indicated several discrete cold zones near the island at site 3 that were missed with nearby FO-DTS cables. Discrete cold patches were found at sites 2 and 3 along the $\mathrm{M}$ zones but not in the $\mathrm{N}$ zones (Fig. 9). The cold anomalies make up a rel- atively small percentage of the overall surveyed area at both $\mathrm{M}$ reaches. The largest cold anomaly is located at the site 2 spring area and indicates a plunging plume of cold water, as discussed earlier. The areal extent of this anomaly is approximately twice as large as the plume footprint measured within the water column, likely indicating an influence from more diffuse groundwater upwelling through the streambed, as detailed in Briggs et al. (2013). Cold riverbed areas were better detected with the discrete snapshot method than with the continuous FO-DTS method, likely because the snapshot measurements were made at $0.05 \mathrm{~m}$ depth and the fiber-optic cable was resting on top of the bed and influenced to a greater extent by surface-water temperatures. The snapshot method also provided better lateral distribution of data collection.

\subsection{Geology of the riverbed}

Consistent spatial patterns of streambed electrical conductivity were observed in multiple adjacent and overlapping EMI lines, but there was no apparent relation between riverbed electrical conductivity and occurrence of DWM (Fig. 4). For example, DWM areas at sites 1 and 3 are located above more 
conductive material, whereas corresponding $\mathrm{N}$ reaches are generally less conductive. Conversely, DWM at site 2 are found over the least-conductive material, whereas the opposite side of the river and $\mathrm{N}$ reach are both more conductive.

\section{Discussion}

Some of the individual methods for characterizing rates and spatial distribution of groundwater discharge produced inconclusive results, indicative of the difficulty presented by such a challenging setting. Collectively, however, they lead to the conclusion that groundwater discharge is related to occurrence and distribution of DWM in the upper Delaware River. Listed from strongest to weakest, the evidence stacks up as follows:

1. Easily visible seeps and springs were present at or just upriver of all three $\mathrm{M}$ reaches but not at the $\mathrm{N}$ reaches.

2. Large lateral hydraulic gradients toward the river indicate the potential for substantial groundwater discharge at all three sites.

3. Upward seepage through the riverbed measured with seepage meters was much faster and more consistently upward at reaches populated by mussels.

4. Median upward vertical hydraulic gradients were 3-9 times larger at $\mathrm{M}$ reaches than at $\mathrm{N}$ reaches.

5. Seepage based on vertical temperature profiles measured with two different methods of instrumentation was upward, circumneutral, and downward, at 2, 5, and 1 of 8 M-reach locations, respectively, whereas temperature-profile-based seepage was downward at all three N-reach locations.

6. Riverbed temperature based on FO-DTS and snapshot streambed thermal surveys was slightly colder in the $\mathrm{M}$ reaches than in the $\mathrm{N}$ reaches; bed temperature was particularly cold in discrete patches that were better captured with the bed temperature snapshot surveys.

Combined results from the first four methods, in particular, provide compelling evidence that groundwater discharge is substantial in areas populated by DWM. Somewhat surprisingly, neither geophysical nor chemical methods were related to presence or absence of DWM. Although patterns were evident, geophysical data showed no clear correlation with $\mathrm{M}$ or $\mathrm{N}$ reaches. Chemistry of groundwater, water removed from in-river piezometers, and surface water was virtually identical, rendering chemistry, often a good indicator of water source, of little use to distinguish $\mathrm{M}$ from $\mathrm{N}$ reaches.

It is also clear that groundwater discharge is not evenly or universally distributed across the $\mathrm{M}$ or $\mathrm{N}$ areas. Hyporheic exchange superimposed on broader-scale groundwater discharge exerts a highly complex flow path distribution that results in variable rates of upward, largely horizontal, and downward seepage across the riverbed. This local-scale variability in seepage direction and rate did not appear to be related to locations of individual DWM. Three pairs of seepage meters and streambed piezometers were installed nearby, and within $1 \mathrm{~m}$ of an individual DWM, without evidence of anomalously strong seepage at specific DWM locations. These three paired observations, along with substantial heterogeneity in seepage rate and direction within each $\mathrm{M}$ reach, indicate that DWM do not require focused groundwater discharge precisely where they are located, but instead rely on the existence of substantial groundwater discharge within or just upstream of their populated area.

Other studies that have investigated the effect of groundwater discharge on benthic invertebrates have yielded mixed results. One study indicated a direct correlation between rate of groundwater discharge and abundance and taxonomic richness (Hunt et al., 2006), while another showed little correlation (Schmidt et al., 2007). Few studies have related groundwater discharge with mussel abundance and species richness. A study conducted in a river with similarly coarse sediment indicated a relation between mussel population density and upward seepage rate (Klos et al., 2015), but upward seepage in that setting was primarily driven by hyporheic exchange. The net upward seepage at DWM sites in the Delaware River, although clearly influenced by hyporheic exchange, is primarily the result of area-wide groundwater discharge as evidenced by substantially faster reach-averaged upward seepage and also colder water along $\mathrm{M}$ reaches relative to $\mathrm{N}$ reaches.

Obtaining direct measurements of groundwater discharge is difficult in settings such as the upper Delaware River where large boulders up to $1 \mathrm{~m}$ or more in diameter are common. Distinguishing hyporheic exchange from groundwater discharge in coarse-grained fluvial settings can also be challenging (e.g., González-Pinzón et al., 2015; Menció et al., 2014; Ward et al., 2013; Bhaskar et al., 2012), hence the multiple lines of evidence pursued for this study. Therefore, few studies of exchange between groundwater and surface water have been successfully conducted in such coarse-grained sediments. Compared to those that have (e.g., Rosenberry et al., 2012; Fritz et al., 2009; Klos et al., 2015), values for point measurements of seepage exchange at these three sites on the Delaware River were not particularly large. This indicates that hyporheic exchange is perhaps smaller than would be expected along $\mathrm{M}$ reaches, given the coarseness of the bed. And, just as was inferred regarding smaller-than-expected $K_{\mathrm{V}}$ values, large horizontal hydraulic gradients adjacent to the river at all three sites would indicate larger amounts of groundwater discharge to the river than were measured, implying the presence of substantially finer-grained sediment beneath the bed surface that is likely leading to focused rapid discharge in isolated locations while at the same time limiting diffuse flow. Flow strong enough to suspend sediments in the water column was observed at many of the bankside 
seeps. Most of the spring discharge at site 2 was focused at two locations above river stage but it clearly was sufficiently rapid to suspend sediments had it been submerged. Discharge through the submerged portion of the spring area at site 2 was also heterogeneous; cold water existed throughout the spring-area sediments but fine-grained sediments were not suspended and seepage rates at S1 and S3 were not remarkably large. Fine- to medium-grained silt was attached to many of the M-reach piezometers upon removal, but no silt was observed on removal of any of the N-reach piezometers. Silts are generally more electrically conductive than gravel and cobbles, but the EMI data showed M reaches were located over a mix of sediment types. The depth-integrated $(\sim 0-12 \mathrm{~m})$ data presented here may not capture a shallow layer of fines. The multi-frequency GEM2 tool can be used at higher frequencies for shallow depth-specific investigation (Briggs et al., 2016), but the use of this higher-frequency data was complicated by the variable depth of surface water, which strongly influences the signals.

Cold-water anomalies were detected along all $\mathrm{M}$ reaches, but never along an $\mathrm{N}$ reach. At site 2, mussel-location data from 2010 and 2012, in particular, indicated a strong clustering of animals directly adjacent to and downstream from the main spring described here and by Briggs et al. (2013) (J. Cole, unpublished data). DWM indeed may be present in these areas due to relatively stable and cold groundwater discharge that serves as a refuge for these animals during periods of lowest river stage. Additionally, mussel surveys have only been taken at these locations during summer months; groundwater discharge also may offer benefits for mussel survival during cold winter extremes that are not apparent based on these data collected during the summer.

Data indicating flow in opposite directions across the riverbed are initially puzzling (Table 2). Hyporheic flow paths in substantially heterogeneous and highly transmissive sediment, a common situation in a cobble-bed river, are predominantly horizontal with small upward and downward flow components. Seepage meters quantify the upward or downward component of flow across the sediment-water interface whether the flow is vertical or largely horizontal. Because piezometers and vertical temperature profilers are installed vertically, thermally derived interpretations of seepage assume vertical flow through the sediments, often a poor assumption in hyporheic settings. It is not uncommon for seepage meters to indicate flow in one direction while hydraulic gradients indicate the opposite (Rosenberry and Pitlick, 2009; Rosenberry et al., 2012; Angermann et al., 2012; Käser et al., 2009). Locations with discordant data are indicative of flow across the sediment-water interface that was largely driven by hyporheic processes, which are superimposed on larger-scale groundwater-discharge patterns (Rosenberry et al., 2012). Hyporheic flow appeared to dominate exchange at the site $3 \mathrm{~N}$ reach. Furthermore, substantial changes in the vertical component of hyporheic flow were indicated at most of the locations where temperature was mea- sured at multiple depths in the riverbed (Table 2), also indicative of hyporheic exchange that is reduced or transitions to horizontal flow with increasing sediment depth (e.g., Briggs et al., 2012b).

\subsection{Methods comparison}

The first four methods listed at the beginning of the discussion section all provide strong evidence for groundwater discharge to the river, although the scale of those measurements was not the same. Large lateral hydraulic gradients based on data from bankside monitoring wells consistently indicated potential for substantial groundwater discharge at all three study sites on a site-wide scale, but those results could not distinguish between groundwater discharge at $\mathrm{M}$ vs. $\mathrm{N}$ reaches. The other three methods were more local in scale, which allowed comparisons of $\mathrm{M}$ and $\mathrm{N}$ reaches. Direct observation of seeps and springs at $M$ but not at $\mathrm{N}$ reaches, faster upward seepage at $\mathrm{M}$ than $\mathrm{N}$ reaches, and larger upward vertical hydraulic gradients at $\mathrm{M}$ not $\mathrm{N}$ reaches all indicate greater groundwater discharge in and near areas populated by DWM. However, for in-river seepage and hydraulic-gradient measurements, these conclusions can only be reached when data are aggregated within each $\mathrm{M}$ or $\mathrm{N}$ reach. Otherwise, local-scale hyporheic exchange greatly confounds the interpretation.

Hyporheic exchange also made it difficult to obtain clear interpretations from temperature-based data. Because shallow hyporheic flow paths in coarse-grained sediments are primarily horizontal and temperature-profile methods assume primarily vertical flow, it should not be surprising that data might be difficult to interpret. Other studies in finer sandbed streams have obtained conclusive and consistent results using these methods (Rosenberry et al., 2016; Hatch et al., 2010). Excluding the questionable temperature-based data in Table 2, when all other location-specific data are aggregated over an entire $\mathrm{M}$ or $\mathrm{N}$ reach, the conclusion is consistent; greater groundwater discharge occurs at $\mathrm{M}$ than at $\mathrm{N}$ reaches.

Given the substantial hyporheic exchange that results in upward flow across the bed with basically the same temperature as the river water, it also is not surprising that the two thermal-reconnaissance methods would not show a strong difference between $\mathrm{M}$ and $\mathrm{N}$ reaches. However, the manually measured snapshot temperature survey still identified colder areas of the sediment bed, but in $\mathrm{M}$ reaches only. The efficacy of the snapshot method was a pleasant surprise, likely because measurements were made at $0.05 \mathrm{~m}$ sediment depth and better indicated the temperature of discharging groundwater.

Only the methods based on geophysics and chemistry provided data of little value. As suggested previously, geologic controls on distribution of seepage may have been of a scale that was impossible to resolve with these geophysical tools. Regarding chemistry, it may be that groundwater flow paths were neither sufficiently long nor groundwater sufficiently 
old, in this headwaters area for groundwater chemistry to have developed a water chemistry distinguishable from river water.

\subsection{Seepage at study sites relative to kilometer-scale values}

Substantial groundwater discharge clearly occurs at areas populated by DWM, and no areas of focused discharge were identified immediately upstream or downstream of these three DWM-populated areas. However, is this prodigious discharge greater than what is typical along the upper reaches of the Delaware River? Fortunately, river discharge can be compared between two USGS gaging stations: Lordville (USGS station number 01427207; http://wterdata.usgs.gov/ nwis) and Callicoon. Several streams enter the river between these two gaging stations, most notably Little Equinunk and Basket Creeks, but these streams are largely dry following prolonged dry periods. During 2013, the average gain in measured river flow between Lordville and the downstream Callicoon stations was $5.9 \mathrm{~m}^{3} \mathrm{~s}^{-1}$. During October, the month with the smallest average river flow, the gain between the two gaging stations was only $2.1 \mathrm{~m}^{3} \mathrm{~s}^{-1}$. Divided by the $29 \mathrm{~km}$ distance between the two gaging stations, and assuming that stream inputs during this low-flow period were minimal, perhaps contributing half of the increase in river discharge, this equates to an average increase in discharge of $2.2 \mathrm{~L} \mathrm{~min}^{-1}$ per $m$ of river reach. Assuming that discharge of groundwater occurs equally on both sides of the river, this equates to an average rate of groundwater discharge of $1.1 \mathrm{~L} \mathrm{~min}^{-1}$ per meter of river along each bank. This value is substantially smaller than most of the point-discharge values that were measured in the various seeps and springs identified along each of these study sites where DWM have been found (Table 3). Furthermore, only the seeps at and slightly above the river bank were identified either visually or with FLIR data. Based on colder locations measured along $\mathrm{M}$ reaches with the profiler data, it is likely that other seeps also were present but they were not observed because they were submerged. Therefore, although groundwater does contribute water to other reaches of the upper Delaware River, the rate of discharge is substantially greater within areas populated by DWM. The link between groundwater discharge and DWM preference for these areas remains unknown, warranting further research. A recent study by Galbraith et al. (2015) indicates that DWM may be less mobile during dewatering caused by reduced river flow than other mussel species. Groundwater discharge may offset the effects of dewatering of the riverbed caused by rapid decreases in river stage.

\section{Conclusions}

Alasmidonta heterodon (dwarf wedgemussels) were located within or slightly downriver from reaches where a prodi-
Table 3. Rates of measured or calculated groundwater discharge. $\Delta Q$ is the difference in river flow between two USGS gaging stations.

\begin{tabular}{llll}
\hline Site & $\begin{array}{l}\text { Measurement } \\
\text { type }\end{array}$ & $\begin{array}{l}\text { Measurement } \\
\text { scale }\end{array}$ & $\begin{array}{l}\text { Seepage rate* } \\
\text { L min }\end{array}$ \\
\hline 1 & spring & point & 6.4 \\
2 & well & site reach & 0.04 to 0.07 \\
2 & spring & point & 12.9 \\
2 & spring & point & 76.5 \\
3 & well & site reach & $3-6 \times 10^{-5}$ \\
3 & spring & point & 0.5 to 2 \\
$1-3$ & $\Delta Q$ & $29 \mathrm{~km}$ reach & 1.1 \\
\hline
\end{tabular}

* Reach-scale seepage rate is per meter of river reach per single side of river.

gious amount of groundwater discharge was observed. Discrete, anomalously cold riverbed areas were detected in all DWM reaches, but never in the reaches where DWM were not detected. Measured discharges from individual seeps and springs ranged from 0.5 to $77 \mathrm{~L} \mathrm{~min}^{-1}$. Discharge also occurred from numerous other visible seeps that were not measurable because it occurred right at the bank or in river water that was less than $5 \mathrm{~cm}$ deep. Horizontal hydraulic gradients measured at water-table wells installed within $12 \mathrm{~m}$ of the river were large and indicated flow from groundwater to the river at all three study sites. Although gradient at site 1 was measured only once, gradients indicating flow toward the river at sites 2 and 3 persisted year-round except for brief periods when they reversed in response to abrupt riverstage rise following large rains or snowmelt. Measurements of groundwater-surface-water exchange at specific points on the riverbed indicated that seepage was upward across the sediment-water interface at 80 percent of DWM locations and 60 percent of non-DWM locations. Median values of seepage along DWM reaches were 0.4 and $3.5 \mathrm{~cm} \mathrm{~d}^{-1}$; median values of seepage at non-DWM reaches were 0.2 and $-0.01 \mathrm{~cm} \mathrm{~d}^{-1}$. Vertical hydraulic gradients indicated upward flow at all locations in DWM reaches and median values were 3 to 9 times larger than at non-DWM reaches. Large rates of hyporheic exchange in places complicated the distinction between groundwater discharge at DWM vs. nonDWM reaches. Streambed-temperature-based seepage measurements guided by thermal surveys (e.g., at cold zones) consistently indicated moderate groundwater upwelling to the river, confirming these as zones of rapid upward seepage. Geology beneath the riverbed, as evaluated by bulk electrical conductivity, was variable at all three study sites, but geologic variability did not appear to be correlated with distribution of DWM.

In conclusion, the collective lines of evidence indicate that DWM are situated in or directly downstream of areas of substantial groundwater discharge to the river. The work presented here and in Briggs et al. (2013) may be the first 
to demonstrate the importance of groundwater discharge to unionid species. Additional work is needed to better understand the linkages between groundwater discharge and presence of DWM as well as geological controls that focus groundwater discharge in these areas.

\section{Data availability}

Data on geomorphic parameters and groundwater-surfacewater exchange are available upon request to Donald Rosenberry. Temperature data, seepage rates determined from measurements of temperature, and geophysical data are available upon request to Martin Briggs.

Acknowledgements. We thank Jeffrey Cole for advice and instructions related to river and riverbed logistics, and Heather Galbraith and Carrie Blakesley for mussel identification and location, all from the USGS Northern Appalachian Research Branch. Don Hamilton from the National Park Service Upper Delaware Recreational and Scenic River, and Joseph Markos, Richfield, MN, are thanked for their field assistance and logistical support. Jason Halm's (University of Colorado-Boulder) exceptional support before, during, and following field work is greatly appreciated. This work was funded by the US Fish and Wildlife Service. Use of trade names is for identification purposes only and does not constitute endorsement by the US Geological Survey.

Edited by: C. Stamm

Reviewed by: two anonymous referees

\section{References}

Angermann, L., Lewandowski, J., Fleckenstein, J. H., and Nützmann, G.: A 3D analysis algorithm to improve interpretation of heat pulse sensor results for the determination of small-scale flow directions and velocities in the hyporheic zone, J. Hydrol., 475, 1-11, doi:10.1016/j.jhydrol.2012.06.050, 2012.

Bhaskar, A. S., Harvey, J. W., and Henry, E. J.: Resolving hyporheic and groundwater components of streambed water flux using heat as a tracer, Water Resour. Res., 48, W08524, doi:10.1029/2011wr011784, 2012.

Bouwer, H. and Rice, R. C.: A slug test for determining hydraulic conductivity of unconfined aquifers with completely or partially penetrating wells, Water Resour. Res., 12, 423-428, 1976.

Bouwer, H.: The Bouwer and Rice slug test - an update, Ground Water, 27, 304-309, 1989.

Braun, D. D.: Surficial geology of the Long Eddy and Callicoon 7.5-minute quadrangles, Wayne County, Pennsylvania, Pennsylvania Geological Survey, Harrisburg, Open-File Surficial Geological Map Report 11-01.0, 13, 2011.

Briggs, M. A., Lautz, L. K., and McKenzie, J. M.: A comparison of fibre-optic distributed temperature sensing to traditional methods of evaluating groundwater inflow to streams, Hydrol. Process., 26, 1277-1290, doi:10.1002/hyp.8200, 2012a.
Briggs, M. A., Lautz, L. K., McKenzie, J. M., Gordon, R. P., and Hare, D. K.: Using high-resolution distributed temperature sensing to quantify spatial and temporal variability in vertical hyporheic flux, Water Resour. Res., 48, W02527, doi:10.1029/2011wr011227, 2012b.

Briggs, M. A., Voytek, E. B., Day-Lewis, F. D., Rosenberry, D. O., and Lane, J. W.: Understanding water column and streambed thermal refugia for endangered mussels in the Delaware River, Environ. Sci. Technol., 47, 11423-11431, doi:10.1021/es4018893, 2013.

Briggs, M. A., Lautz, L. K., Buckley, S. F., and Lane, J. W.: Practical limitations on the use of diurnal temperature signals to quantify groundwater upwelling, J. Hydrol., 519, 1739-1751, doi:10.1016/j.jhydrol.2014.09.030, 2014.

Briggs, M. A., Campbell, S., Nolan, J., Walvoord, M. A., Ntarlagiannis, D., Day-Lewis, F. D., and Lane, J. W.: Surface geophysical methods for characterising frozen ground in transitional permafrost landscapes, Permafrost Periglac., in press, doi:10.1002/ppp.1893, 2016.

Buffington, J. M. and Montgomery, D. R.: A systematic analysis of eight decades of incipient motion studies, with special reference to gravel-bedded rivers, Water Resour. Res., 33, 1993-2029, 1997.

Cole, J. C., Townsend, P. A., and Eshleman, K. N.: Predicting flow and temperature regimes at three Alasmidonta heterodon locations in the Delaware River, National Park Service, Philadelphia, Technical Report NPS/NER/NRTR-2008/109, 66, 2008.

Constantz, J.: Heat as a tracer to determine streambed water exchanges, Water Resour. Res., 44, W00D10, doi:10.1029/2008wr006996, 2008.

Fritz, B. G., Mendoza, D. P., and Gilmore, T. J.: Development of an electronic seepage chamber for extended use in a river, Ground Water, 47, 136-140, 2009.

Galbraith, H. S., Blakeslee, C. J., and Lellis, W. A.: Recent thermal history influences thermal tolerance in freshwater mussel species (Bivalvia:Unionoida), Freshw. Sci., 31, 83-92, doi:10.1899/11025.1, 2012.

Galbraith, H. S., Blakeslee, C. J., and Lellis, W. A.: Behavioral responses of freshwater mussels to experimental dewatering, Freshw. Sci., 34, 42-52, 2015.

González-Pinzón, R., Ward, A. S., Hatch, C. E., Wlostowski, A. N., Singha, K., Gooseff, M. N., Haggerty, R., Harvey, J. W., Cirpka, O. A., and Brock, J. T.: A field comparison of multiple techniques to quantify groundwater-surface-water interactions, Freshw. Sci., 34, 139-160, 2015.

Gordon, R. P., Lautz, L. K., Briggs, M. A., and McKenzie, J. M.: Automated calculation of vertical pore-water flux from field temperature time series using the VFLUX method and computer program, J. Hydrol., 420-421, 142-158, doi:10.1016/j.jhydrol.2011.11.053, 2012.

Hardison, B. S. and Layzer, J. B.: Relations between complex hydraulics and the localized distribution of mussels in three regulated rivers, Regul. River., 17, 77-84, 2001.

Hare, D. K., Briggs, M. A., Rosenberry, D. O., Boutt, D. F., and Lane, J. W.: A comparison of thermal infrared to fiberoptic distributed temperature sensing for evaluation of groundwater discharge to surface water, J. Hydrol., 530, 153-166, doi:10.1016/j.jhydrol.2015.09.059, 2015. 
Hatch, C. E., Fisher, A. T., Revenaugh, J. S., Constantz, J., and Ruehl, C.: Quantifying surface water-groundwater interactions using time series analysis of streambed thermal records: Method development, Water Resour. Res., 42, W10410, doi:10.1029/2005WR004787, 2006.

Hatch, C. E., Fischer, A. T., Ruehl, C. R., and Stemler, G.: Spatial and temporal variations in streambed hydraulic conductivity quantified with time-series thermal methods, J. Hydrol., 389, 276-288, 2010.

Hayashi, M. and Rosenberry, D. O.: Effects of ground water exchange on the hydrology and ecology of surface water, Ground Water, 40, 309-316, 2002.

Hunt, R. J., Strand, M., and Walker, J. F.: Measuring groundwatersurface water interaction and its effect on wetland stream benthic productivity, Trout Lake watershed, northern Wisconsin, USA, J. Hydrol., 320, 370-384, 2006.

Irvine, D. J., Lautz, L. K., Briggs, M. A., Gordon, R. P., and McKenzie, J. M.: Experimental evaluation of the applicability of phase, amplitude, and combined methods to determine water flux and thermal diffusivity from temperature time series using VFLUX 2, J. Hydrol., 531, 728-737, doi:10.1016/j.jhydrol.2015.10.054, 2015.

Käser, D. H., Binley, A., Heathwaite, A. L., and Krause, S.: Spatiotemporal variations of hyporheic flow in a riffle-step-pool sequence, Hydrol. Process., 23, 2138-2149, 2009.

Klos, P. Z., Rosenberry, D. O., and Nelson, G. R.: Influence of hyporheic exchange, substrate distribution, and other physically-linked hydrogeomorphic characteristics on abundance of freshwater mussels, Ecohydrology, 8, 1284-1291, doi:10.1002/eco.1581, 2015.

Koch, F. W., Voytek, E. B., Day-Lewis, F. D., Healy, R., Briggs, M. A., Lane, J. W., and Werkema, D.: 1DTempPro V2: new features for inferring groundwater/surface-water exchange, Ground Water, 54, 434-439, doi:10.1111/gwat.12369, 2016.

Lautz, L. K. and Ribaudo, R. E.: Scaling up point-in-space heat tracing of seepage flux using bed temperatures as a quantitative proxy, Hydrogeol. J., 20, 1223-1238, doi:10.1007/s10040-0120870-2, 2012

Layzer, J. B. and Madison, L. M.: Microhabitat use by freshwater mussels and recommendations for determining their instream flow needs, Regul. River., 10, 329-345, 1995.

Maloney, K. O., Lellis, W. A., Bennett, R. M., and Waddle, T. J.: Habitat persistence for sedentary organisms in managed rivers: the case for the federally endangered dwarf wedgemussel (Alasmidonta heterodon) in the Delaware River, Freshw. Biol., 57, 1315-1327, doi:10.1111/j.1365-2427.2012.02788.x, 2012.

Martin, G. D., Dennis, C. A., and Malmgren, R. C.: Soil survey of Wayne County, Pennsylvania, US Department of Agriculture Soil Conservation Service, Washington DC, 119, 1985.

McRae, S. E., Allan, J. D., and Burch, J. B.: Reach- and catchmentscale determinants of the distribution of freshwater mussels (Bivalvia: Unionidae) in south-eastern Michigan, USA, Freshw. Biol., 49, 127-142, 2004.

Menció, A., Galán, M., Boix, D., and Mas-Pla, J.: Analysis of stream-aquifer relationships: A comparison between mass balance and Darcy's law approaches, J. Hydrol., 517, 157-172, doi:10.1016/j.jhydrol.2014.05.039, 2014.
Moser, G. A.: Dwarf wedge mussel (Alasmidonta heterodon) recovery plan, US Fish and Wildlife Service, Hadley, Massachusetts, 52 pp., 1993.

Neilson, B. T., Hatch, C. E., Ban, H., and Tyler, S. W.: Solar radiative heating of fiber-optic cables used to monitor temperatures in water, Water Resour. Res., 46, W08540, doi:10.1029/2009WR008354, 2010.

Ong, J. B., Lane Jr., J. W., Zlotnik, V. A., Halihan, T., and White, E. A.: Combined use of frequency-domain electromagnetic and electrical resistivity surveys to delineate near-lake groundwater flow in the semi-arid Nebraska Sand Hills, USA, Hydrogeol. J., 18, 1539-1545, 2010.

Rosenberry, D. O.: A seepage meter designed for use in flowing water, J. Hydrol., 359, 118-130, 2008.

Rosenberry, D. O. and Pitlick, J.: Local-scale spatial and temporal variability of seepage and hydraulic conductivity in a shallow gravel-bed river, Hydrol. Process., 23, 3306-3318, 2009.

Rosenberry, D. O., LaBaugh, J. W., and Hunt, R. J.: Use of monitoring wells, portable piezometers, and seepage meters to quantify flow between surface water and ground water, in: Field techniques for estimating water fluxes between surface water and ground water edited by: Rosenberry, D. O., and LaBaugh, J. W., US Geological Survey Techniques and Methods 4-D2, Denver, 39-70, 2008.

Rosenberry, D. O., Klos, P. Z., and Neal, A.: In situ quantification of spatial and temporal variability of hyporheic exchange in static and mobile gravel-bed rivers, Hydrol. Process., 26, 604 612, doi:10.1002/hyp.8154, 2012.

Rosenberry, D. O., Briggs, M. A., Delin, G., and Hare, D. K.: Combined use of thermal methods and seepage meters to efficiently locate, quantify, and monitor focused groundwater discharge to a sand-bed stream, Water Resour. Res., 52, 4486-4503, doi:10.1002/2016WR018808, 2016.

Rovey II, C. W. and Cherkauer, D. S.: Scale dependency of hydraulic conductivity measurements, Ground Water, 33, 769-780, 1995.

Schmidt, S. I., Hellweg, J., Hahn, H. J., Hatton, T. J., and Humphreys, W. F.: Does groundwater influence the sediment fauna beneath a small, sandy stream?, Limnologica, 37, 208-225, 2007.

Schulze-Makuch, D., Carlson, D. A., Cherkauer, D. S., and Malik, P.: Scale dependency of hydraulic conductivity in heterogeneous media, Ground Water, 37, 904-919, 1999.

Selker, J. S., Thevenaz, L., Huwald, H., Mallet, A., Luxemburg, W., van de Giesen, N., Stejskal, M., Zeman, J., Westhoff, M., and Parlange, M. B.: Distributed fiber-optic temperature sensing for hydrologic systems, Water Resour. Res., 42, W12202, doi:10.1029/2006WR005326, 2006.

Shvidchenko, A. B., Pender, G., and Hoey, T. B.: Critical shear stress for incipient motion of sand/gravel streambeds, Water Resour. Res., 37, 2273-2283, 2001.

Smith, J. W. N.: Groundwater-surface water interactions in the hyporheic zone, Environment Agency, Almondsbury, Science Report SC030155/SR1, 65, 2005.

Voytek, E. B., Drenkelfuss, A., Day-Lewis, F. D., Healy, R., Lane, J. W., and Werkema, D.: 1DTempPro: Analyzing Temperature Profiles for Groundwater/Surface-water Exchange, Ground Water, 52, 298-302, doi:10.1111/gwat.12051, 2014. 
Ward, A. S., Payn, R. A., Gooseff, M. N., McGlynn, B. L., Bencala, K. E., Kelleher, C. A., Wondzell, S. M., and Wagener, T.: Variations in surface water-ground water interactions along a headwater mountain stream: Comparisons between transient storage and water balance analyses, Water Resour. Res., 49, 3359-3374, doi:10.1002/wrcr.20148, 2013.
Wolman, M. G.: A method of sampling coarse river-bed material, Transactions of the American Geophysical Union, 35, 951-956, 1954. 